\title{
When Marriage Hurts: A Literature Review of Embedded Jewellery Ring Injuries
}

\author{
Sameem Tak ${ }^{1}$, Esmee Irvine ${ }^{2}$, Muzamil Baba ${ }^{3}$, Vinayak Ghanate ${ }^{3}$, Hamidreza Khairandish ${ }^{3}$ \\ 1. Trauma and Orthopaedics, University Hospitals of Leicester, Leicester, GBR 2. Plastic Surgery, Leeds General \\ Infirmary, Leeds, GBR 3. Trauma and Orthopaedics, Kettering General Hospital, Kettering, GBR
}

Corresponding author: Sameem Tak, s.tak@nhs.net

\begin{abstract}
A ring is traditionally worn as a symbol of love and affection or as decorative ornamental jewellery. However, rings are not without risk. The spectrum of danger can range from debilitating avulsion injuries to simple contact dermatitis. Unknown to many, an unusual rarity exists; previous authors have termed this entity 'embedded ring syndrome'. We sought to review the literature and collate evidence on the common features of this syndrome.
\end{abstract}

A literature review was performed on cases reported from 1947 to 2017 accessed through the healthcare database advanced search (HDAS). A total of 28 cases were analysed for demographics, symptomatology and operative techniques. Overall, $64.3 \%$ were females, and $50 \%$ had a psychiatric comorbidity. There was a causative event preceding the injury in $35.7 \%$ of cases; $71.4 \%$ had a reduced range of movement or reported a stiff finger and $32.1 \%$ had reduced sensation. The majority of patients underwent ring removal and primary closure, without documentation as to whether neurovascular bundles and tendons were visualised.

Embedded ring injuries are rare. Consequently, information is sparsely available regarding its natural history and management. The hand surgeon's approach requires an understanding that the chronicity of these injuries can have a significant traumatic impact on the structures of the finger.

Review began 10/22/2020 Review ended 11/12/2020 Published 11/22/2020

๑) Copyright 2020

Tak et al. This is an open access article distributed under the terms of the Creative Commons Attribution License CC-BY 4.0., which permits unrestricted use, distribution, and reproduction in any medium, provided the original author and source are credited.
Categories: Plastic Surgery, Orthopedics, Trauma

Keywords: hand injury, ring injury, embedded ring, trauma, tourniquet

\section{Introduction And Background}

It is believed that ancient Egyptians first established the custom of ring bearing to reflect the eternity of their marriage: impervious and unbroken. Legend has it that they bore rings on the fourth finger as vena amoris connected this digit directly to the heart. Such a vein does not exist; indeed, the circulatory system was unknown at the time $[1,2]$.

Today, many people choose to wear a ring or 'wedding band', which is usually forged from metal. Commonly, ring entrapment can occur secondary to the swelling of a digit. It is unmoveable past the proximal interphalangeal joint secondary to pregnancy, allergic reaction or infection, or simply as a result of a tightfitting ring. There are well-established methods for entrapped ring removal in the emergency department such as the winding technique, which uses thread to compress the finger, or using manual ring cutters to saw the ring [3]. Rarely, they can result in complex traumatic avulsion injuries to the hand when the ring is caught on an object and forcefully pulled. These injuries can necessitate a range of treatments, from simple wound closure through to microvascular repair and amputation [4]. Rarer still, a ring can become embedded into the soft tissue of a digit to the extent that it is not at all visible to the eye. This unusual phenomenon has previously been described as 'embedded ring syndrome' [5]. An embedded ring can be seen as the re-epithelialisation of skin over any part of the ring resulting in the formation of a skin bridge. Figure 1 shows an example of an embedded ring. The literature is limited to sporadic case reports, and the majority of authors have presented their cases in the context of extreme rarity. Within this review, we aim to amalgamate the available data and identify the common features. 


\section{Cureus}

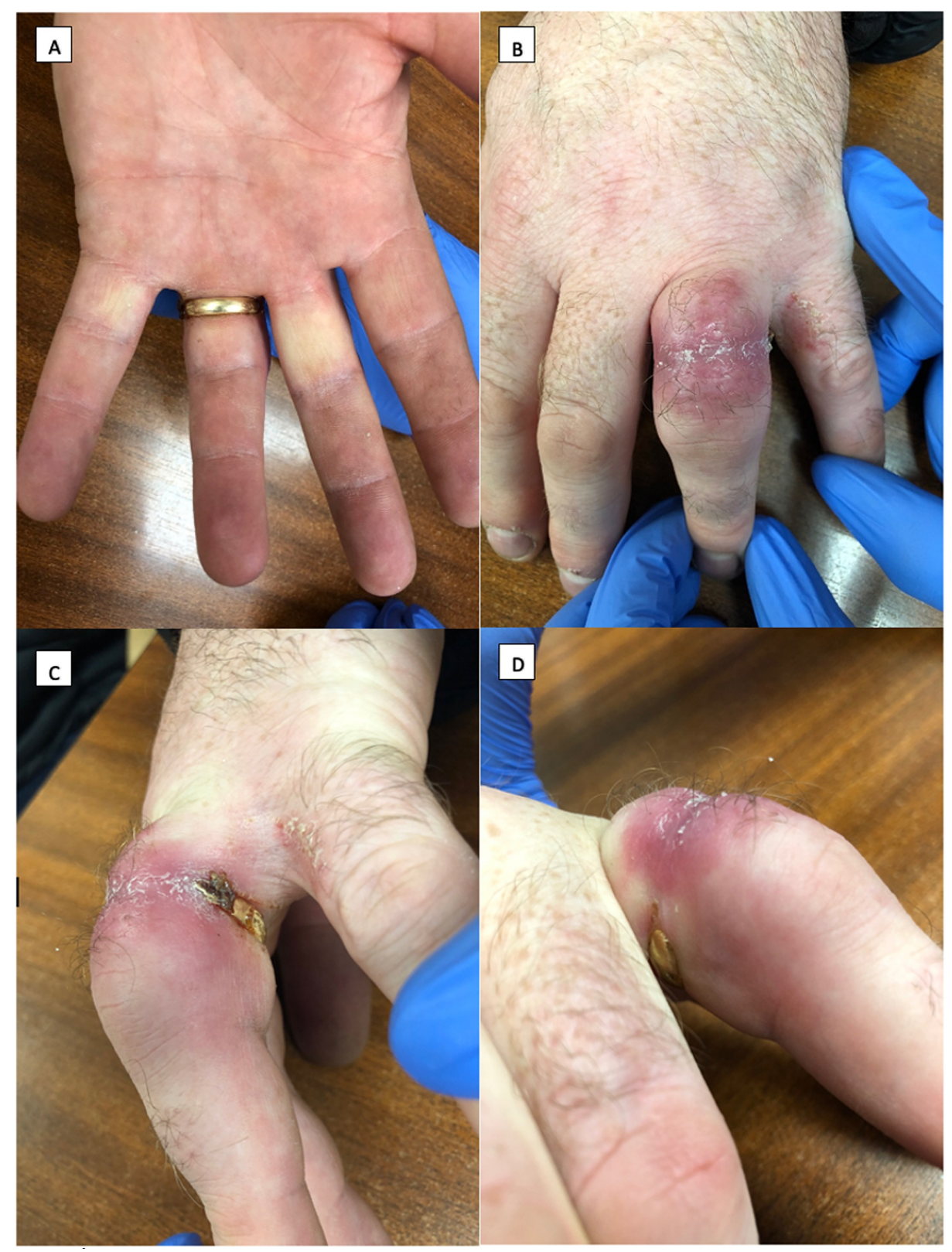

FIGURE 1: (A-D) Example of an embedded ring injury

\section{Review}

We utilised the National Institute for Health and Care Excellence (NICE) Healthcare Database Advanced Search (HDAS) via OpenAthens to search PubMed, MEDLINE, EMBASE and EMCARE databases from their inception until August 2020. The following search terms were used: 'embedded ring injury/injuries' or 'ring injury/injuries' or 'embedded ring syndrome' both independently and combined with 'ulceration' 'erosion' 'digit' 'finger' or 'retained.' Articles were included for patients of any age range and demographic. Excluded articles were those that described ring injuries without any epithelialisation/'skin bridge' over the ring, articles relating to ring entrapment rather than embedded rings and articles not written in English text.

Figure 2 shows an outline of the systematic literature search that was carried out in accordance with the Preferred Reporting Items for Systematic Reviews and Meta-Analyses System (PRISMA) statement for study selection [6]. Two authors independently screened the 60 articles that were retrieved through the database search. The references of retrieved articles were traced for citations missed by the electronic search; this yielded a further six articles. Thirty one irrelevant and duplicate articles were removed. Three articles were excluded as they were presented in a foreign language. After screening, 32 full-text articles were selected for further evaluation: five articles were excluded as they were non-embedded cases. A total of 27 were finally put forward for analysis; 26 articles presented one case each and one article presented two cases. There was no disagreement in study selection between authors. 


\section{Cureus}
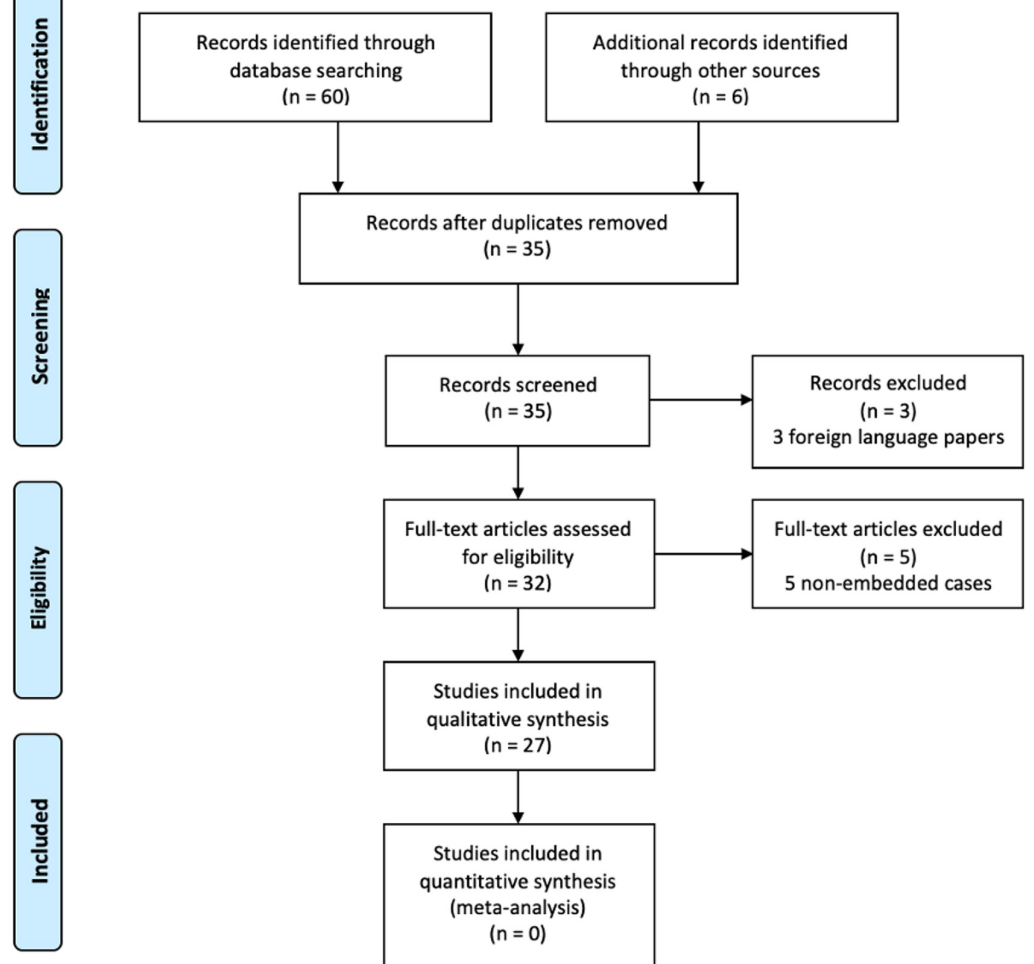

\section{FIGURE 2: Outline of article selection process}

Flow diagram of the Preferred Reporting Items for Systematic Reviews and Meta-Analyses (PRISMA) process.

A total of 27 reports were analysed dating from 1947 to 2017 [5,7-32]. Given its unusual and rare nature, some of the information reported was sporadic and without structure. Information regarding patient demographics, symptomatology and operative techniques were collected where available. Table 1 shows the patient demographics and any reported causative event, as well as the reported length of time over which the injury had occurred.

\begin{tabular}{|c|c|c|c|c|c|c|c|c|}
\hline Author & Gender & Age & Medical Comorbidity & $\begin{array}{l}\text { Psychiatric } \\
\text { Comorbidity }\end{array}$ & Causative Event & $\begin{array}{l}\text { Duration of } \\
\text { Symptoms }\end{array}$ & $\begin{array}{l}\text { No. of Digits } \\
\text { Involved }\end{array}$ & Digit(s) \\
\hline Awan et al. [7] & $F$ & 16 & - & Intellectual disability & No & - & 1 & Index finger \\
\hline $\begin{array}{l}\text { Balakrishnan and } \\
\text { Nyitray [8] }\end{array}$ & $\mathrm{F}$ & 24 & - & Intellectual disability & - & - & 1 & Ring finger \\
\hline Bennett et al. [9] & M & 13 & - & - & No & 1 month & 1 & Ring finger \\
\hline Zeng et al. [10] & M & 18 & No & $\begin{array}{l}\text { yes; secondary to } \\
\text { amphetamine abuse }\end{array}$ & Trauma & 2 weeks & 1 & Middle finger \\
\hline $\begin{array}{l}\text { Deshmukh and } \\
\text { Stothard [11] }\end{array}$ & M & 22 & - & Yes; unspecified & - & - & 1 & Middle finger \\
\hline Drake et al. [12] & $\mathrm{F}$ & 39 & - & Yes; unspecified & - & - & 1 & Middle finger \\
\hline $\begin{array}{l}\text { Drewniany et } \\
\text { al. [13] }\end{array}$ & $\mathrm{F}$ & 62 & $\begin{array}{l}\text { Diabetes mellitus, } \\
\text { cerebrovascular accident }\end{array}$ & - & No & - & 1 & Ring finger \\
\hline
\end{tabular}




\section{Cureus}

\begin{tabular}{|c|c|c|c|c|c|c|c|c|}
\hline Jamison [5] & M & 28 & - & - & No & - & 1 & Ring finger \\
\hline Freedman [14] & $\mathrm{F}$ & 73 & $\begin{array}{l}\text { Heart failure, diabetes } \\
\text { mellitus, anaemia }\end{array}$ & - & Trauma & 9 years & 1 & Ring finger \\
\hline $\begin{array}{l}\text { Hove and } \\
\text { Odland [15] }\end{array}$ & $\mathrm{F}$ & 36 & - & Intellectual disability & - & 31 years & 1 & Ring finger \\
\hline Kattan et al. [16] & $\mathrm{F}$ & 17 & - & - & Trauma & 3 months & 1 & - \\
\hline Kumar et al. [17] & M & 49 & - & $\begin{array}{l}\text { Schizophrenia, } \\
\text { depression }\end{array}$ & Trauma & 3 months & 1 & Index finger \\
\hline $\begin{array}{l}\text { Kuschner et } \\
\text { al. [18] }\end{array}$ & M & 44 & - & Yes; unspecified & - & - & 2 & $\begin{array}{l}\text { Ring and middle } \\
\text { finger }\end{array}$ \\
\hline $\begin{array}{l}\text { Kuschner et } \\
\text { al. [18] }\end{array}$ & M & 48 & - & Schizophrenia & - & - & 1 & Thumb \\
\hline $\begin{array}{l}\text { Langridge et } \\
\text { al. [19] }\end{array}$ & $\mathrm{F}$ & 45 & No & No & Insect Bite & $\begin{array}{l}\text { Several } \\
\text { months }\end{array}$ & 1 & Ring finger \\
\hline Leung and Ip [20] & M & 71 & - & No & - & - & 1 & Ring finger \\
\hline $\begin{array}{l}\text { Magos \& } \\
\text { Sheikh [21] }\end{array}$ & $\mathrm{F}$ & 71 & $\begin{array}{l}\text { Subarachnoid } \\
\text { haemorrhage }\end{array}$ & No & Trauma & 9 weeks & 1 & Ring finger \\
\hline Moore et al. [22] & M & 41 & HIV & Schizophrenia & - & $\begin{array}{l}\text { Several } \\
\text { years }\end{array}$ & 1 & Index finger \\
\hline Prasad et al. [23] & $\mathrm{F}$ & 7 & - & - & - & 4 years & 1 & Index finger \\
\hline $\begin{array}{l}\text { Reguesse et } \\
\text { al. [24] }\end{array}$ & $\mathrm{F}$ & 69 & No & No & No & - & 1 & Ring finger \\
\hline Rohilla et al. [25] & M & 22 & - & No & Trauma & 1 week & 1 & Middle finger \\
\hline Saltz et al. [26] & $\mathrm{F}$ & 23 & - & Yes; unspecified & - & $\begin{array}{l}\text { Several } \\
\text { months }\end{array}$ & 1 & Little finger \\
\hline Shafiroff [27] & $\mathrm{F}$ & 29 & - & Intellectual disability & $\begin{array}{l}\text { Rapid weight } \\
\text { gain }\end{array}$ & 4 months & 1 & Ring finger \\
\hline Sleilati et al. [28] & $\mathrm{F}$ & 63 & - & Intellectual disability & - & - & 1 & Ring finger \\
\hline $\begin{array}{l}\text { Uemura et } \\
\text { al. [29] }\end{array}$ & $\mathrm{F}$ & 73 & No & Yes; unspecified & $\begin{array}{l}\text { Trauma and rapid } \\
\text { weight gain }\end{array}$ & 10 years & 1 & Ring finger \\
\hline Unlü et al. [30] & $\mathrm{F}$ & 54 & No & No & No & 1 year & 3 & $\begin{array}{l}\text { Ring, middle and } \\
\text { index finger }\end{array}$ \\
\hline Witt [31] & $\mathrm{F}$ & 8 & No & No & Trauma & 3 months & 1 & Ring finger \\
\hline Woodhouse [32] & $\mathrm{F}$ & 47 & - & - & - & 3 months & 1 & Ring finger \\
\hline
\end{tabular}

\section{TABLE 1: Patient demographics}

Note: Unrecorded data are represented by '-'

Patients ranged from 7 to 73 years of age. Excluding the three paediatric patients aged 7, 8 and 13, there was an average adult age of 43.3 years; $64.3 \%$ were female $(n=18)$ and $35.7 \%$ were male $(n=10)$. Also, $64.3 \%$ of authors $(n=18)$ did not comment on any medical comorbidities, $21.4 \%$ reported none $(n=6)$ and $14.3 \%$ stated patient comorbidities $(\mathrm{n}=4)$.

Of the 28 patients, $50 \%(n=14)$ had a psychiatric comorbidity, whilst $25 \%(n=7)$ had none; the remaining $25 \%$ $(n=7)$ of reports did not make any reference to psychiatric comorbidity. The diagnoses included intellectual disability, schizophrenia, mental illness secondary to drug abuse and depression. Five authors referred to a psychiatric comorbidity but did not specify the diagnosis. None of the three paediatric cases reported a psychiatric diagnosis. 


\section{Cureus}

Of the patients, 35.7\% ( $\mathrm{n}=10)$ reported a causative event correlating to the onset of symptoms. This included a clear history of traumatic injury to the finger, rapid weight gain and insect bite. Also, 21.4\% $(n=6)$ reported no obvious preceding event, and for the remaining $42.9 \%(\mathrm{n}=12)$, no information was given or a history could not be obtained due to psychiatric comorbidity.

Overall, 60.7\% ( $n=17)$ reported a time duration of symptoms before presentation whilst 39.3\% ( $n=11)$ did not. Three authors did not objectively quantify the reported durations, instead they referred to the time period as 'several months/years'. Of the patients, $7.1 \%(\mathrm{n}=2)$ had embedded ring symptoms develop over less than one month, $32.1 \%(n=9)$ developed over one month to one year and $21.4 \%(n=6)$ developed over the course of more than one year; $39.3 \%(\mathrm{n}=11)$ did not report a duration of symptoms.

There were two cases of rings embedded on multiple fingers, and the remainder of cases involved only one digit. The ring finger was the most common digit to have an embedded ring. Figure 3 shows the distribution of embedded rings by finger involved.

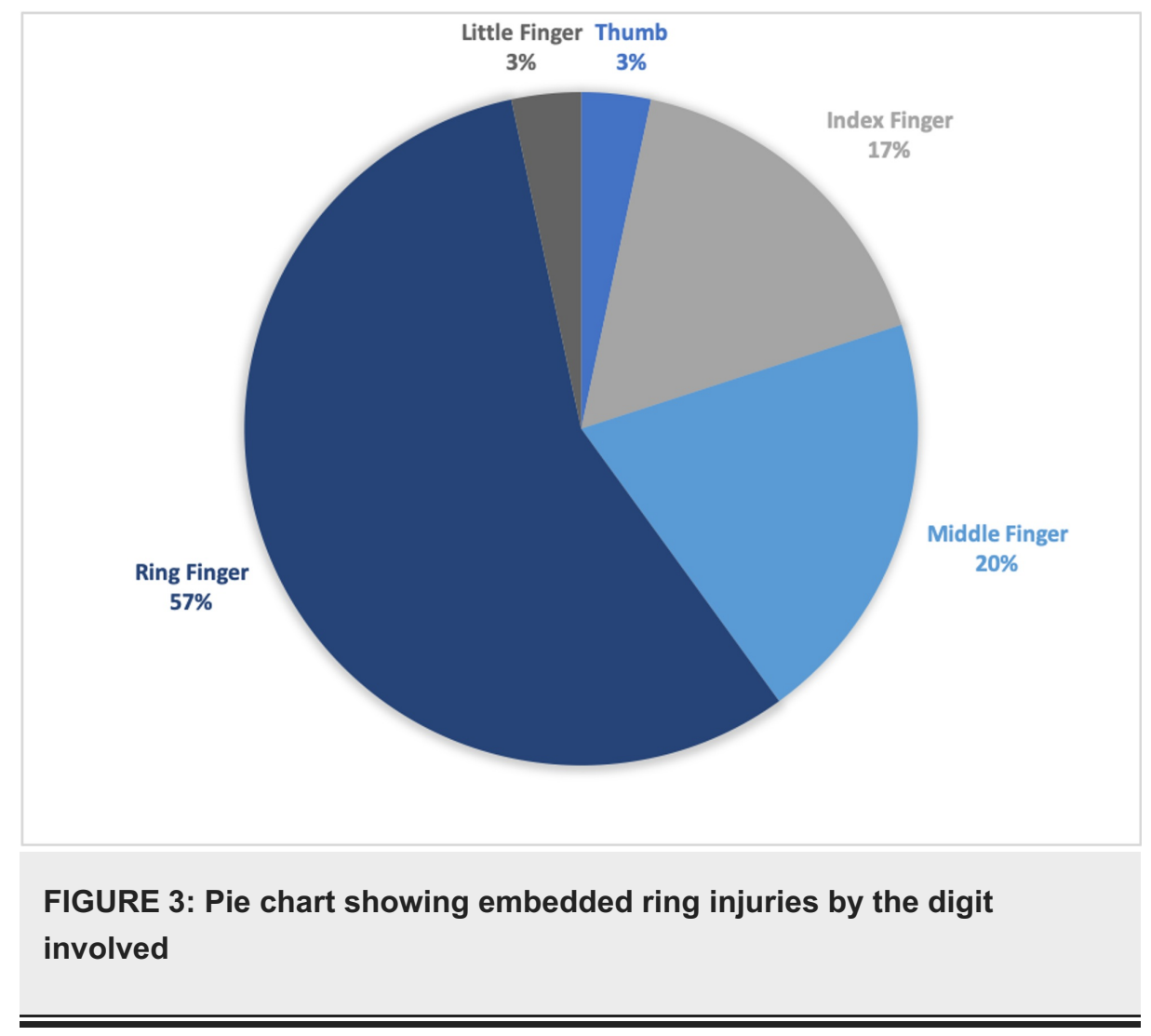

Table 2 shows the clinical findings recorded of the patients with embedded rings. The commonest position of a skin bridge was on the volar aspect of the finger $(67.9 \%, n=19)$. Dorsal skin bridges occurred in $10.7 \%$ $(\mathrm{n}=3)$. Completely circumferential skin bridges (i.e. an invisible ring) occurred in $10.7 \%(\mathrm{n}=3)$. Position of skin bridge was not clear in two cases (7.1\%). One case (3.6\%) had near-complete embedding: skin bridging on the dorsal, volar and ulnar border of the finger but visibility of the ring on the radial border. Moreover, $35.7 \%(n=10)$ had pain/discomfort, $21.4 \%(n=6)$ had no pain/discomfort and $42.9 \%(n=12)$ did not report upon this finding. 


\section{Cureus}

\begin{tabular}{|c|c|c|c|c|c|c|c|c|c|}
\hline Author & $\begin{array}{l}\text { Position of Skin Bridge on } \\
\text { Finger }\end{array}$ & $\begin{array}{l}\text { Discomfort/Pain in } \\
\text { Finger }\end{array}$ & Vascular Status & $\begin{array}{l}\text { Distal } \\
\text { Sensation }\end{array}$ & $\begin{array}{l}\text { Bony } \\
\text { Involvement }\end{array}$ & $\begin{array}{l}\text { IPJ } \\
\text { Movement }\end{array}$ & Erythema & Swelling & $\begin{array}{l}\text { Signs of } \\
\text { Infection }\end{array}$ \\
\hline Awan et al. [7] & $\begin{array}{l}\text { Volar, dorsal and ulnar } \\
\text { border }\end{array}$ & No & Normal & Normal & No & Normal & Yes & Yes & No \\
\hline $\begin{array}{l}\text { Balakrishnan and } \\
\text { Nyitray [8] }\end{array}$ & - & - & Normal & Normal & No & Normal & - & - & Yes \\
\hline Bennett et al. [9] & Complete circumferential & - & Normal & Normal & Yes & Reduced & - & Yes & Yes \\
\hline Zeng et al. [10] & Volar & Yes & Normal & Reduced & - & Reduced & Yes & Yes & Yes \\
\hline $\begin{array}{l}\text { Deshmukh and } \\
\text { Stothard [11] }\end{array}$ & Volar & Yes & Normal & Normal & No & Reduced & - & Yes & No \\
\hline Drake et al. [12] & Volar & - & Normal & Normal & Yes & Reduced & - & Yes & No \\
\hline Drewniany et al. [13] & Volar & $\cdot$ & Normal & Reduced & Yes & Reduced & - & - & - \\
\hline Fraser and Jamison [5] & Volar & Yes & Normal & Normal & No & Reduced & - & Yes & - \\
\hline Freedman [14] & Volar & - & - & - & Yes & Reduced & - & Yes & No \\
\hline Hove and Odland [15] & Dorsal & Yes & Normal & Normal & Yes & Reduced & - & Yes & Yes \\
\hline Kattan et al. [16] & Volar & - & - & - & Yes & - & - & - & - \\
\hline Kumar et al. [17] & Volar & Yes & $\begin{array}{l}\text { Delayed CRT of } 5 \\
\text { seconds }\end{array}$ & Reduced & - & Reduced & Yes & Yes & - \\
\hline Kuschner et al. [18] & Dorsal & - & Normal & Reduced & No & Reduced & - & Yes & No \\
\hline Kuschner et al. [18] & Volar & - & Normal & Normal & - & Reduced & - & - & - \\
\hline Langridge et al. [19] & Volar & No & Normal & Normal & No & Normal & No & Yes & No \\
\hline Leung and Ip [20] & Volar & Yes & Normal & Normal & Yes & Reduced & - & Yes & Yes \\
\hline Magos and Sheikh [21] & Volar & No & Normal & Normal & - & Normal & - & - & No \\
\hline Moore et al. [22] & - & - & Normal & Reduced & No & Reduced & - & Yes & No \\
\hline Prasad et al. [23] & Dorsal & No & Normal & - & Yes & Reduced & - & Yes & - \\
\hline Reguesse et al. [24] & Volar & Yes; minimal & Normal & Reduced & No & $\begin{array}{l}\text { Reduced; } \\
\text { stiff }\end{array}$ & Yes & Yes & No \\
\hline Rohilla et al. [25] & Complete circumferential & Yes & Normal & Normal & No & - & - & - & - \\
\hline Saltz et al. [26] & Volar & No & Normal & Normal & - & - & No & Yes & Yes \\
\hline Shafiroff [27] & Volar & $\cdot$ & Delayed CRT & Normal & - & - & Yes & Yes & Yes \\
\hline Sleilati et al. [28] & Volar & Yes & Normal & Hyperaesthesia & Yes & Reduced & Yes & Yes & - \\
\hline Uemura et al. [29] & Volar & - & Normal & Reduced & No & $\begin{array}{l}\text { Reduced; } \\
\text { stiff }\end{array}$ & Yes & Yes & Yes \\
\hline Unlü et al. [30] & Volar & - & Normal & Reduced & Yes & $\begin{array}{l}\text { Reduced; } \\
\text { stiff }\end{array}$ & Yes & Yes & No \\
\hline Witt [31] & Complete circumferential & No & Normal & Reduced & Yes & Reduced & Yes & Yes & No \\
\hline Woodhouse [32] & Volar & Yes & Normal & Normal & - & Reduced & Yes & Yes & Yes \\
\hline
\end{tabular}

TABLE 2: Comparison of clinical findings between reported cases

IPJ, interphalangeal joint; CRT, capillary refill time

Note: Unrecorded data are represented by '-' 
The vast majority had normal vascular supply in the digit (85.7\%; $\mathrm{n}=24)$, two reported delayed capillary refill times $(7.1 \%)$ and $7.1 \%(n=2)$ did not report upon vascular status. Distal to the site of injury, $53.6 \%(n=15)$ had normal sensation and 32.1\% ( $n=9)$ had reduced sensation. And, 3.6\% $(n=1)$ had hyperaesthesia, 10.7\% $(n=3)$ did not report upon sensation, $39.3 \%(\mathrm{n}=11)$ had a ring embedded into bone in addition to soft tissues, $35.7 \%(n=10)$ did not involve bone and $25 \%(n=7)$ were unreported.

Of the patients, $71.4 \%(n=20)$ had a reduced range of movement or reported a stiff finger. Normal range of movement (ROM) was described in $14.3 \%(n=4)$. Erythema was present in $35.7 \%(n=10)$ and absent in $7.2 \%$ $(\mathrm{n}=2)$. All cases that commented upon swelling stated that it was present in the offending finger $(78.6 \%$; $n=22) ; 32.1 \%$ showed signs of infection $(n=9)$ and $39.3 \%$ showed no signs of infection $(n=11)$.

Table 3 shows the intraoperative findings. The available data on this aspect was sparse. A majority of authors reported using ring cutters to release the ring, with two using wire cutters and one using a tapered fissure burr. Only seven authors stated that they explored the wounds. Five authors commented on tendon integrity, with three reporting some degree of tendon rupture. Two authors reported collateral vessel formation as a result of the embedded ring, with Awan et al. showing a neurovascular bundle traversing over the top of an embedded ring [7].

\begin{tabular}{|c|c|c|c|c|c|c|}
\hline Author & $\begin{array}{l}\text { Mode of } \\
\text { Anaesthetic }\end{array}$ & Incision & $\begin{array}{l}\text { Wound } \\
\text { Exploration }\end{array}$ & $\begin{array}{l}\text { Instrument } \\
\text { for Ring } \\
\text { Removal }\end{array}$ & Intraoperative Course & Follow-Up \\
\hline Awan et al. [7] & Regional & Yes & Yes & $\begin{array}{l}\text { Ring } \\
\text { cutters }\end{array}$ & $\begin{array}{l}\text { Intact NVB and flexor tendons, } \\
\text { neovascularisation, growth of NVB over top } \\
\text { of ring: repair not required }\end{array}$ & $\begin{array}{l}\text { Residual } \\
\text { stiffness }\end{array}$ \\
\hline $\begin{array}{l}\text { Balakrishnan } \\
\text { and Nyitray [8] }\end{array}$ & - & - & - & - & - & $\begin{array}{l}\text { Return of } \\
\text { normal ROM }\end{array}$ \\
\hline $\begin{array}{l}\text { Bennett et } \\
\text { al. [9] }\end{array}$ & - & Yes & Yes & $\begin{array}{l}\text { Ring } \\
\text { cutters }\end{array}$ & Intact NVB & $\begin{array}{l}\text { Return to } \\
\text { near-normal } \\
\text { ROM }\end{array}$ \\
\hline Zeng et al. [10] & - & No & No & $\begin{array}{l}\text { Ring } \\
\text { cutters }\end{array}$ & - & - \\
\hline $\begin{array}{l}\text { Deshmukh and } \\
\text { Stothard [11] }\end{array}$ & - & - & - & $\begin{array}{l}\text { Ring } \\
\text { cutters }\end{array}$ & - & - \\
\hline Drake et al. [12] & General & Yes & No & $\begin{array}{l}\text { Ring } \\
\text { cutters }\end{array}$ & - & $\begin{array}{l}\text { Restricted } \\
\text { ROM }\end{array}$ \\
\hline $\begin{array}{l}\text { Drewniany et } \\
\text { al. [13] }\end{array}$ & - & - & - & $\begin{array}{l}\text { Ring } \\
\text { cutters }\end{array}$ & - & $\begin{array}{l}\text { Restricted } \\
\text { ROM, residual } \\
\text { sensory } \\
\text { disturbance }\end{array}$ \\
\hline $\begin{array}{l}\text { Fraser and } \\
\text { Jamison [5] }\end{array}$ & - & - & - & $\begin{array}{l}\text { Ring } \\
\text { cutters }\end{array}$ & $\begin{array}{l}\text { Intact NVB, intact flexor and extensor } \\
\text { tendons }\end{array}$ & - \\
\hline Freedman [14] & - & - & - & - & - & $\begin{array}{l}\text { Restricted } \\
\text { ROM }\end{array}$ \\
\hline $\begin{array}{l}\text { Hove and } \\
\text { Odland [15] }\end{array}$ & Local & No & No & $\begin{array}{l}\text { Ring } \\
\text { cutters }\end{array}$ & - & $\begin{array}{l}\text { Restricted } \\
\text { ROM }\end{array}$ \\
\hline Kattan et al. [16] & - & - & - & - & - & - \\
\hline Kumar et al. [17] & - & Yes & No & $\begin{array}{l}\text { Ring } \\
\text { cutters }\end{array}$ & - & $\begin{array}{l}\text { Return of } \\
\text { normal } \\
\text { sensation, } \\
\text { restricted } \\
\text { ROM }\end{array}$ \\
\hline $\begin{array}{l}\text { Kuschner et } \\
\text { al. [18] }\end{array}$ & - & - & - & - & - & - \\
\hline $\begin{array}{l}\text { Kuschner et } \\
\text { al. [18] }\end{array}$ & General & Yes & - & $\begin{array}{l}\text { Ring } \\
\text { cutters }\end{array}$ & - & $\begin{array}{l}\text { Restricted } \\
\text { ROM }\end{array}$ \\
\hline
\end{tabular}




\section{Cureus}

\begin{tabular}{|c|c|c|c|c|c|c|}
\hline $\begin{array}{l}\text { Langridge et } \\
\text { al. [19] }\end{array}$ & General & Yes & Yes & $\begin{array}{l}\text { Wire } \\
\text { cutters }\end{array}$ & - & - \\
\hline $\begin{array}{l}\text { Leung and } \\
\text { Ip [20] }\end{array}$ & Local & Yes & Yes & $\begin{array}{l}\text { Ring } \\
\text { cutters }\end{array}$ & $\begin{array}{l}\text { Ruptured FDS, ruptured extensor digitorum, } \\
\text { normal radial NVB (ulnar NVB not explored): } \\
\text { tenolysis and tenosynovectomy of flexors } \\
\text { and extensors }\end{array}$ & $\begin{array}{l}\text { Return of } \\
\text { normal ROM }\end{array}$ \\
\hline $\begin{array}{l}\text { Magos and } \\
\text { Sheikh [21] }\end{array}$ & Local & No & No & $\begin{array}{l}\text { Ring } \\
\text { cutters }\end{array}$ & - & Normal \\
\hline Moore et al. [22] & General & No & No & $\begin{array}{l}\text { Tapered } \\
\text { fissure } \\
\text { burr }\end{array}$ & - & $\begin{array}{l}\text { Improved } \\
\text { ROM, residual } \\
\text { sensory } \\
\text { disturbance }\end{array}$ \\
\hline $\begin{array}{l}\text { Prasad et } \\
\text { al. [23] }\end{array}$ & General & - & - & - & - & $\begin{array}{l}\text { Improved } \\
\text { ROM }\end{array}$ \\
\hline $\begin{array}{l}\text { Reguesse et } \\
\text { al. [24] }\end{array}$ & - & No & No & $\begin{array}{l}\text { Ring } \\
\text { cutters }\end{array}$ & - & $\begin{array}{l}\text { Residual } \\
\text { stiffness, } \\
\text { residual } \\
\text { sensory } \\
\text { disturbance }\end{array}$ \\
\hline $\begin{array}{l}\text { Rohilla et } \\
\text { al. [25] }\end{array}$ & Local & - & - & $\begin{array}{l}\text { Ring } \\
\text { cutters }\end{array}$ & - & Normal \\
\hline Saltz et al. [26] & Local & Yes & No & $\begin{array}{l}\text { Wire } \\
\text { cutters }\end{array}$ & - & - \\
\hline Shafiroff [27] & General & No & No & $\begin{array}{l}\text { Ring } \\
\text { cutters }\end{array}$ & - & - \\
\hline $\begin{array}{l}\text { Sleilati et } \\
\text { al. [28] }\end{array}$ & General & - & - & - & - & $\begin{array}{l}\text { Return of } \\
\text { normal } \\
\text { sensation, } \\
\text { restricted } \\
\text { ROM }\end{array}$ \\
\hline $\begin{array}{l}\text { Uemura et } \\
\text { al. [29] }\end{array}$ & Regional & Yes & Yes & $\begin{array}{l}\text { None } \\
\text { required }\end{array}$ & $\begin{array}{l}\text { Ruptured FDP, compressed NVB: patient } \\
\text { refused repair }\end{array}$ & $\begin{array}{l}\text { Return of } \\
\text { normal } \\
\text { sensation, } \\
\text { restricted } \\
\text { ROM }\end{array}$ \\
\hline Unlü et al. [30] & - & - & - & - & Neovascularisation & $\begin{array}{l}\text { Residual } \\
\text { stiffness }\end{array}$ \\
\hline Witt [31] & - & Yes & Yes & $\begin{array}{l}\text { Ring } \\
\text { cutters }\end{array}$ & - & $\begin{array}{l}\text { Residual } \\
\text { stiffness }\end{array}$ \\
\hline Woodhouse [32] & General & Yes & Yes & - & Partially ruptured FDS: no repair & $\begin{array}{l}\text { Return of } \\
\text { normal ROM }\end{array}$ \\
\hline
\end{tabular}

\section{TABLE 3: Reported intraoperative data}

NVB, neurovascular bundle(s); ROM, range of movement; FDP, flexor digitorum profundus; FDS, flexor digitorum superficialis

Note: Unrecorded data are represented by '-'

Twenty authors reported follow-up findings at varying lengths of time postoperatively. Six patients had an improvement in their interphalangeal joint ROM/stiffness, whilst 12 showed no improvement at follow-up. Three patients had an improvement in their sensibility, whilst three had residual sensory disturbance.

The term 'embedded ring syndrome' has previously been used to describe the association of this injury with psychiatric illness [5]. Initial case reports in the literature pointed towards a prerequisite of mental illness to develop an embedded ring; however, as shown in our review, it is not an absolute requirement; $25 \%$ of 
All three of the paediatric cases had radiographic evidence of the ring eroding into the proximal phalanx $[9,23,31]$. A possible explanation for this unusual phenomenon may be that as the ring embeds, the child's finger continues to grow, and the embedded ring is encompassed into the growing bone. These cases also highlight that there may be delays in presentation and diagnosis, owing to the child's lack of insight or sense of deep embarrassment [9].

Adult cases with evidence of bony erosion reported a long duration of symptoms ( 9 years, 10 years and 31 years), supporting the suggestion that chronicity increases the risk of bony involvement [14-15,29]. A 17year-old patient was found to have an embedded ring in her proximal phalanx, with a reported symptom duration of three months; this time period may have been shortened since the patient had not reached skeletal maturity [16]. We recommend that radiographs are indicated when presented with an embedded ring injury, firstly, to identify any bony involvement and, secondly, to detect any hidden rings that may not be identified on clinical examination $[9,28]$.

There was a clear history of a causative event in $35.7 \%(n=10)$ of patients, and the most common history was one of a traumatic insult adjacent to the ring. It could logically follow that traumatic disruption of the epithelium combined with the chronic circumferential constriction of a ring provides an opening through which the ring can ulcerate down the subcutaneous layer to the bone. Reepithelialisation then occurs atop the ring. Almost all cases reported digital swelling. This is secondary to the mechanical obstruction of the ring causing venous congestion and disruption to lymphatic drainage [17]. Given the chronicity of symptoms and confounding psychiatric factors, it is likely that small traumatic events to the finger are underreported by the patient.

Two authors reported delayed capillary refill times, but there was no evidence of ischaemic necrosis in any patient, and none required amputation. The embedded ring is a rigid metal structure and is not collapsible; indeed, patients present with rings that have been embedded for many years but show no sign of vascular compromise. This is in contrast to a collapsible structure that acts as a tourniquet, such as in hair tourniquet syndrome [33]. However, the sample size of 28 patients is too small to draw a definitive conclusion that embedded rings do not lead to ischaemia. Additionally, given the thicker periosteum and open physis, the risk of ischaemia cannot be dismissed in a paediatric patient as growth occurs, which may result in the occlusion of neurovascular structures.

The majority of patients underwent surgical ring removal and primary closure, without documentation as to whether neurovascular bundles and tendons were visualised. Given that a majority of patients $(71.4 \%, \mathrm{n}=20)$ presented with reduced range of movement (which persisted at follow-up), it is possible that tendon damage was present but not visualised.

Only one author performed operative repair; tenolysis and tenosynovectomy were performed after finding ruptured flexor and extensor tendons [20]. Regarding the neurovascular bundle, compression of the bundle was the only adverse finding reported on this structure [29]. The sensory disturbance that results from the embedded ring is likely due to neuropraxia secondary to oedema and direct pressure on the nerve from the adjacent ring.

\section{Learning points}

1. When there is any traumatic injury adjacent to a ring, the ring should be removed until the injury has healed.

2. Ischaemia is unlikely to be a feature of embedded ring injuries; however, available data are sparse and a theoretical risk still exists.

3. Embedded rings are not exclusive to the psychiatric population.

4. Radiographs should always be obtained in embedded ring injuries to identify bony involvement and hidden rings not visible on clinical examination.

\section{Conclusions}

Embedded ring injuries are rare. Consequently, information is sparsely available regarding its natural history and management. The hand surgeon's approach requires an understanding that the chronicity of these injuries can have a significant traumatic impact on the structures of the finger.

The responsible healthcare professional should consider the patient's mental health status when determining whether wound exploration and structural repair should be performed. A discussion should be had with the patient regarding the possibility of tendon or nerve repair in addition to ring removal to identify the patient's expectations. Given the preponderance of psychiatric diagnoses in the embedded ring 
injury population, clear treatment goals should be identified.

\section{Additional Information \\ Disclosures}

Conflicts of interest: In compliance with the ICMJE uniform disclosure form, all authors declare the following: Payment/services info: All authors have declared that no financial support was received from any organization for the submitted work. Financial relationships: All authors have declared that they have no financial relationships at present or within the previous three years with any organizations that might have an interest in the submitted work. Other relationships: All authors have declared that there are no other relationships or activities that could appear to have influenced the submitted work.

\section{References}

1. Baker F: Anthropological notes on the human hand . Am Anthropologist. 1888, 1:51-76.

2. Hort GM: Some traditions about rings. Irish Monthly. 1919, 47:649-54.

3. Kalkan A, Kose O, Tas M, Meric G: Review of techniques for the removal of trapped rings on fingers with a proposed new algorithm. Am J Emerg Med. 2013, 31:1605-1611. 10.1016/j.ajem.2013.06.009

4. Bamba R, Malhotra G, Bueno RA, Thayer WP, Shack RB: Ring avulsion injuries: a systematic review . Hand. 2018, 13:15-22. 10.1177/1558944717692094

5. Fraser KE, Jamison DA: Embedded-ring syndrome. Ann Emerg Med.1995. 25:856-857. 10.1016/s01960644(95)70225-3

6. Moher D, Liberati A, Tetzlaff J, Altman DG; The PRISMA Group: Preferred reporting items for systematic reviews and meta-analyses: the PRISMA statement. PLoS Med. 2009, 6:1000097. 10.1371/journal.pmed.1000097

7. Awan B, Samargandi OA, Aljaaly HA, Makhdom AM: Single patent vessel over an embedded ring: a case report. Hand Surg. 2013, 18:125-128. 10.1142/S0218810413720118

8. Balakrishnan C, Nyitray J: Unusual presentation of a ring injury in a psychiatric patient . J Psychosoc Nurs Ment Health Serv. 1999, 37:37-38.

9. Bennett KG, Brou JA, Levine NS: Completely embedded ring in the finger of a growing child . Ann Plast Surg. 1995, 34:76-77. 10.1097/00000637-199501000-00015

10. Zeng BW, Guo YJ, Huang CC: Embedded ring injury of the middle finger in an amphetamine abuser . J Chin Med Assoc. 2006, 69:95-97. 10.1016/S1726-4901(09)70122-4

11. Deshmukh NV, Stothard JS: The embedded ring injury: case report and review of literature . Hand Surg. 2003, 8:103-105. 10.1142/s0218810403001492

12. Drake DA, Lewis F, Newmeyer WL, Kilgore ES Jr: An unusual ring injury. J Hand Surg. 1977, 2:111-112. 10.1016/s0363-5023(77)80093-2

13. Drewniany JJ, Palmer AK, Levinsohn EM: An unusual presentation of a ring injury. J Hand Surg. 1982, 7:194195. 10.1016/s0363-5023(82)80087-7

14. Freedman BJ: Ulceration of wedding-ring into phalanx. BMJ. 1947, 2:1034. 10.1136/bmj.2.4538.1034-a

15. Hove LM, Odland P: Chronic erosion of a digit caused by a ring case report . Scand J Plast Reconstr Surg Hand Surg. 1993, 27:237-238. 10.3109/02844319309078117

16. Kattan KR, Babcock DS, Felson B: Solitary phalangeal defect in the hand. Report of 2 rare cases . Am J Roentgenol Radium Ther Nucl Med. 1975, 124:29-31. 10.2214/ajr.124.1.29

17. Kumar A, Edwards H, Lidder S, Mestha P: Dangers of neglect: partially embedded ring upon a finger . BMJ Case Rep. 2013, 2013:2013009501. 10.1136/bcr-2013-009501

18. Kuschner SH, Gellman H, Hume M: Embedded ring injuries. Clin Orthop Rel Res. 1992, 276:192-193.

19. Langridge BJ, Ramman S, Toft NJ: Embedded ring injury - a rare presentation with an atypical aetiology . Int Wound J. 2017, 14:1052-1054. 10.1111/iwj.12759

20. Leung YF, Ip SPS: Chronic erosion injury of a digit by a ring: epidemiology, staging, treatment and prognosis. Br J Plast Surg. 2002, 55:353-355. 10.1054/bjps.2002.3835

21. Magos TA, Sheikh Z: An embedded finger ring. J Emerg Med. 2015, 48:470-471. 10.1016/j.jemermed.2014.09.051

22. Moore FO, Thornton BP, Shiroff AM, Zabel DD, Vasconez HC: Two partially embedded rings resulting in chronic erosion of a finger. Del Med J. 2004, 76:431-434.

23. Prasad S, Patil U, Thatte R: Insiduous erosion of a digit by a ring . J Hand Surg. 1986, 11:269-270.

24. Reguesse AS, Szwebel JD, Schmitt T, Levan P: When love becomes eternal: two embedded rings, a case report. Annales de Chirurgie Plastique et Esthetique. 2017, 62:109-112. 10.1016/j.anplas.2016.03.008

25. Rohilla N, Jain S, Naranje S, Neogi D, Yadav CS, Kotwal P: Post traumatic completely embedded ring. Eur J Orthop Surg Traumatol. 2009, 19:269-271. 10.1007/s00590-009-0429-7

26. Saltz R, Fix J, Crotting JC: Sapphire ring constriction syndrome. Ann Plast Surg. 1988, 21:375-379. 10.1097/00000637-198810000-00014

27. Shafiroff BB: Easy removal of a partially embedded ring from a finger . Plast Reconstr Surg. 1979, 63:841842 .

28. Sleilati F, Claude O, Werther JR, Ebelin M, Doursounian L: Chronic finger constriction by completely embedded rings: one ring may hide another. Plast Reconstr Surg. 2004, 114:1674-1676.

29. Uemura T, Takamatsu K, Okada M, Ikeda M, Nakamura H: Entrapment of digital nerves due to an embedded ring: a case report. J Reconstr Microsurg. 2014, 30:659-661. 10.1055/s-0034-1370362

30. Unlü C, Loon Jv, Maas M: Seventeen embedded rings resulting in chronic erosion injuries to four digits . J Hand Surg Eur Vol. 2007, 32:719-720. 10.1016/J.JHSE.2007.06.006

31. Witt P: Uncommon features of an uncommon problem: embedded ring syndrome in a child . Plast Reconstr Surg. 2007, 119:1631-1632. 10.1097/01.prs.0000256524.38562.48

32. Woodhouse C: Ulceration of a ring into a phalanx . Hand. 1976, 8:186-188. 


\section{Cureus}

33. Cevik Y, Kavalci C: Hair tourniquet syndrome. Ann Saudi Med. 2010, 30:416-417. 10.4103/0256-4947.67088 